\title{
'n Herlesing van Pseudo-Dionisius se metafisika
}

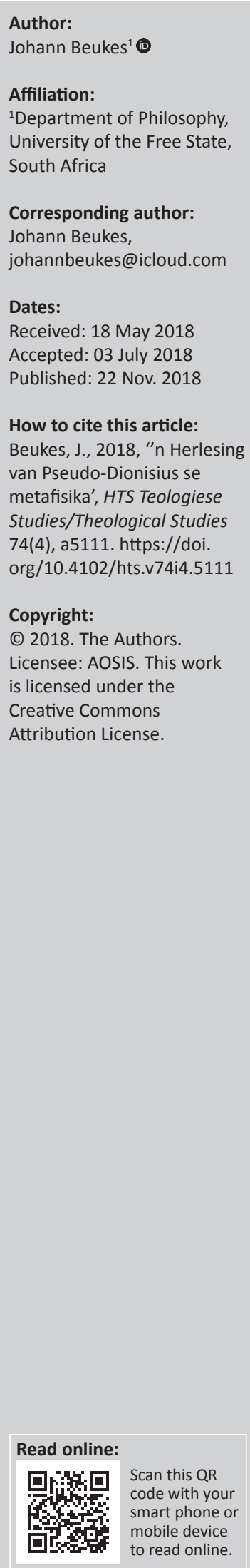

This article, by analysing, annotating en interpreting the most recent research in all relevant departments, provides a fresh and updated overview of the Neoplatonic metaphysics of Pseudo-Dionysius (ca. 500). After providing an introduction to Dionysius' metaphysics in terms of the contributions of Middle Platonism and Neoplatonism, the article explores his broader philosophical system. A number of traits that are uniquely Dionysic-metaphysical, are eventually isolated: the interpretation of transcendence as bound to immanence; the affirmation of God's transcendence in the world (that is, a metaphysics of 'creation as teophany'; following E.D. Perl); the radical transcendence and simultaneous radical immanence of God (that is, God as 'Beingness'); fundamental restrictions of language and the analogical 'Naming' of God; creation as a system of dialectical symbols about God; the analogical participation of the subject in creation; and unification (reditus, the 'flowing of things back to God'). These traits are utilised to reappraise the metaphysics of Nicholas of Cusa (1401-1464) in a subsequent article.

\section{Inleiding}

Hierdie artikel, ${ }^{1}$ met inbegrip van 'n analitiese en sintetiese verwerking van die mees resente navorsing, herlees Pseudo-Dionisius (ca. 500) se metafisika vanuit die erfenisse van MiddelPlatonisme en Neoplatonisme. Daarna word Dionisius se unieke metafisika oopgedek en tendensieuse, idiosinkratiese temas in sy metafisika uitgewys. Die artikel dra by tot die Dionisiusnavorsing deur die merkwaardige opbloei ${ }^{2}$ in die betreklik resente literatuur (oor 'n denker wat buite die nisnavorsing as obskuur geag word en wat daarom in inleidings- en oorsigwerke tot die Middeleeuse filosofie feitlik sonder uitsondering verbygegaan word) op te dateer en kontekstueel te annoteer.

Hierdie idiosinkratiese temas vanuit Dionisius se metafisika sluit die volgende in: die verstaan van transendensie as verknoop met immanensie; die bevestiging van God se transendensie in die wêreld (waar sterk geleun word op E.D. Perl [2007] se lesing van Dionisius, synde'n verstaan van 'skepping as teofanie'); die radikale transendensie en tegelyk radikale immanensie van God (oftewel, in Dionisius se Neoplatoniese taal, 'God as Synheid'); taalbeperktheid en die onvermydelikheid van die analogiese 'be-Naming' van God; Skepping as 'n stelsel van dialektiese simbole oor God; die analogiese deelname van die subjek aan die werklikheid, en 'eenwording' of reditus, die Neoplatoniese opvatting dat alle dinge 'terugvloei na God'.

In Handelinge 17:16-34 word vertel van ene 'Dionisius', 'n filosoof en lid van die Areopagus, wat tot bekering gekom het op sterkte van die Apostel Paulus se prediking. ${ }^{3}$ Bykans vyf eeue later word vier tekste en 'n stel briewe gesirkuleer, wat op grond van die biografiese verwysings daarin (anekdotes wat onder meer spreek van 'n persoonlike verbintenis met Paulus, Petrus en Jakobus, die broer van Jesus; asook die bywoning van Maria, die moeder van Jesus, se begrafnis), en ook die filosofiese erudisie daarvan, dit duidelik maak dat die outeur homself as vermelde 'Dionisius die Areopagiet' aanbied. Hoewel daar aanvanklik huiwering was om die tekste as outentiek te aanvaar, het die tekste betreklik vinnig die soort prestige en outoriteit verkry wat normaalweg gereserveer was vir outeurs van tekste wat oorspronklike en historiese bindinge aan die apostels

1.Die doel van hierdie artikel is om ' $n$ analitiese en argumentatiewe platform te skep vanwaar Dionisius se metafisika as skugter informerend tot die metafisika van Nikolaus van Kusa (1401-1464) uitgewys kan word in 'n opvolgartikel (Beukes 2018). Die diskursiewe oogmerk van beide artikels is om hierdie palimpses logies en sistematies te ondersoek. Die aard van hierdie artikel is enersyds oorsigtelik, in die sin dat grondig aandag gegee word aan die relevante intellektuele geskiedenis. Die artikel is andersyds analities en sinteties, bedoelende dat die primêre tekste so selfstandig moontlik gelees word sonder sekondêre teksbegeleiding, waarna die sekondêre tekste geraadpleeg en getoets word aan die outeur se lesing, om tot 'n koherente sintese te kom.

2.Vgl. Beierwaltes (1997); Billion (2008); Casarella (2008); Duclow (2002); Goosen (2017, ten aansien van 'n interpretasie van E.D. Perl, waarskynlik die mees uitstaande eietydse Dionisius-navorser); O'Rourke (1992); Perl (2006, 2007); Rorem (1993); Tarrant (2011).

3. Hierdie bespreking oor Pseudo-Dionisius is gebaseer op 'n analise en sintese van die gelysde primêre tekste van Pseudo-Dionisius (1988, 1990), asook die volgende sekondêre tekste: Bosley en Tweedale (2004:547-555); Copleston (1993:91-100); Haren (1985:7577); Hathaway (1969:xiii-xxiv); Hyman, Walsh en Williams (2010:141-144); Luscombe (1997:23-29); Marenbon (1988:18-20); O'Rourke (1992:3-21); Perl (2006:540-549; 2007:1-16;111-114); Rorem (1993:3-38) en Sheldon-Williams (1967:457-472). 
van die vroegste kerk gehad het. Dit sou eeue neem voordat die werklikheid sou deurdring dat hierdie 'Dionisius die Areopagiet' 'n pseudonieme skrywer was, wat die betrokke eienaam as skuilnaam gebruik het, ten einde die sirkulasie van sy tekste sover moontlik te verhoog.

Dit was eers nadat tekstuele bewyse dat die outeur konseptueel ooglopend afhanklik was van die Neoplatonis Proklus (412485) se werk, die lig laat sien het, wat uiteraard daarop dui dat die outeur minstens eers in die eeu ná Proklus kon geleef het, dat die outeur herbenaam is na 'Pseudo-Dionisius'. ${ }^{4}$ Die outeur se werk het onder hierdie gerespekteerde skuilnaam 'Dionisius' die ontwikkelende netwerk van Middeleeuse filosofiese konsepte binnegedring, veral in die werk van Skotus Eriugena (815-877), Thomas Aquinas (1225-1274) en, soos in die opvolgartikel (Beukes 2018) aangedui sal word, Nikolaus van Kusa (1401-1464). Pseudo-Dionisius, wie hy ook al in werklikheid was (moontlik wel'n Siriese monnik vanuit die laat vyfde $^{5}$ en vroeg sesde eeu), het gekom om te bly (vgl. Copleston 1993:91-100 en Perl 2006:540). ${ }^{6}$

Wie hy ook al was, (Pseudo-)Dionisius ${ }^{7}$ was 'n oorspronklike en kreatiewe denker. Hy gebruik byvoorbeeld die tipiese drie-vlak deling wat ons in Neoplatonisme aantref om kreatief oor die transendensie van God, met inbegrip van die begrensdheid van die intellek om die Goddelike ten volle te begryp, te praat. Hieronder sal uitgewys word dat Dionisius in die spreke oor God drieledig werk met via affirmativa, via negativa en via eminentiae. Die via affirmativa [bevestigende manier] beteken die toekenning van positiewe eienskappe aan God omdat God (volgens Dionisius) self die oorsaak van daardie eienskappe in skepsels is. Maar as ons oor God soos wat God in Godself is wil praat, sal ons dit in die negatief moet doen: dan moet ons juis ontken dat God oor enige van daardie eienskappe beskik (via negativa). Dit is wanneer ons deur taal self opgevoed word om oor die Syn van God in God se transendensie te praat, dat ons op 'n stil, 'eminente manier' oor God kan praat (via eminentiae).

Beide Augustinus en Boethius het in Latyn geskryf en in die Weste gebly, in Noord-Afrika en die omstreke van Rome. In die oostelike gedeeltes van die Romeinse Ryk was Grieks egter steeds die dominante akademiese taal en Griekse

4.Ook genoem 'Pseudo-Dionisius die Areopagiet' of Pseudo-Dionysius the Areopagite ook Pseudo-Denys. Vir feitlik die hele Middeleeuse periode is daar dus na PseudoDionisius gewoon as 'Dionisius' verwys. Hierby kan ook die bykomende verwarring rondom die anekdotiese derde-eeuse Denis, biskop van Parys, onthoofde martelaar en latere beskermheilige van Frankryk, wat pertinent met die Areopagiet in en latere beskermheilige van Frankryk, wat pertinent met die Areopagiet in
Handelinge 17 geassosieer is, in ag geneem word. Denis is aanvanklik vroeg Handelinge 17 geassosieer is, in ag geneem word. Denis is aanvanklik vroeg
gedateer in die tyd van keiser Domitianus (81-96), wat daardie verwarring vererger het, maar latere daterings plaas Denis tydens die regeertyd van Decius (249-251), deur wie Denis waarskynlik onthoof is.

5.Let daarop dat syfers van een tot nege uitgeskryf word en vanaf 10 konsekwent pe Arabiese syfer aangedui word.

6.Alhoewel pseudepigrafie ' $n$ bekende verskynsel in die antieke wêreld was, teologies selfs tot nog in die patristiese periode, het dit filosofies selde in Middel-Platonisme en Neoplatonisme voorgekom. Porphyreus sou dit byvoorbeeld glad nie oorweeg het om Plotinus se posisie te verhelder deur pseudepigrafies namens Plotinus te skryf nie. Hy het dit eerder onderbeklemtoond onder sy eie naam gedoen. Dit is eers in die $15 \mathrm{e}$ eeu, en later en finaal in die $19 \mathrm{e}$ eeu, met behulp van pertinente kruisverwysings tussen Proklus en (Pseudo-)Dionisius, teenspraakvry vasgestel dat Dionisius 'n skuilnaam was en dat die ware identiteit van die outeur ons waarskynlik vir altyd sal ontwyk.

7.Van hier af word na die outeur van die vier tekste en stel briewe in die hoofteks slegs as 'Dionisius' verwys, in ooreenstemming met die gangbare werkswyse in die Middeleeuse navorsing om hierdie eienaam te gebruik, maar slegs nadat hierdie pseudonieme kwessie uitgeklaar is (vgl. Hathaway 1969:xiii-xxiv).

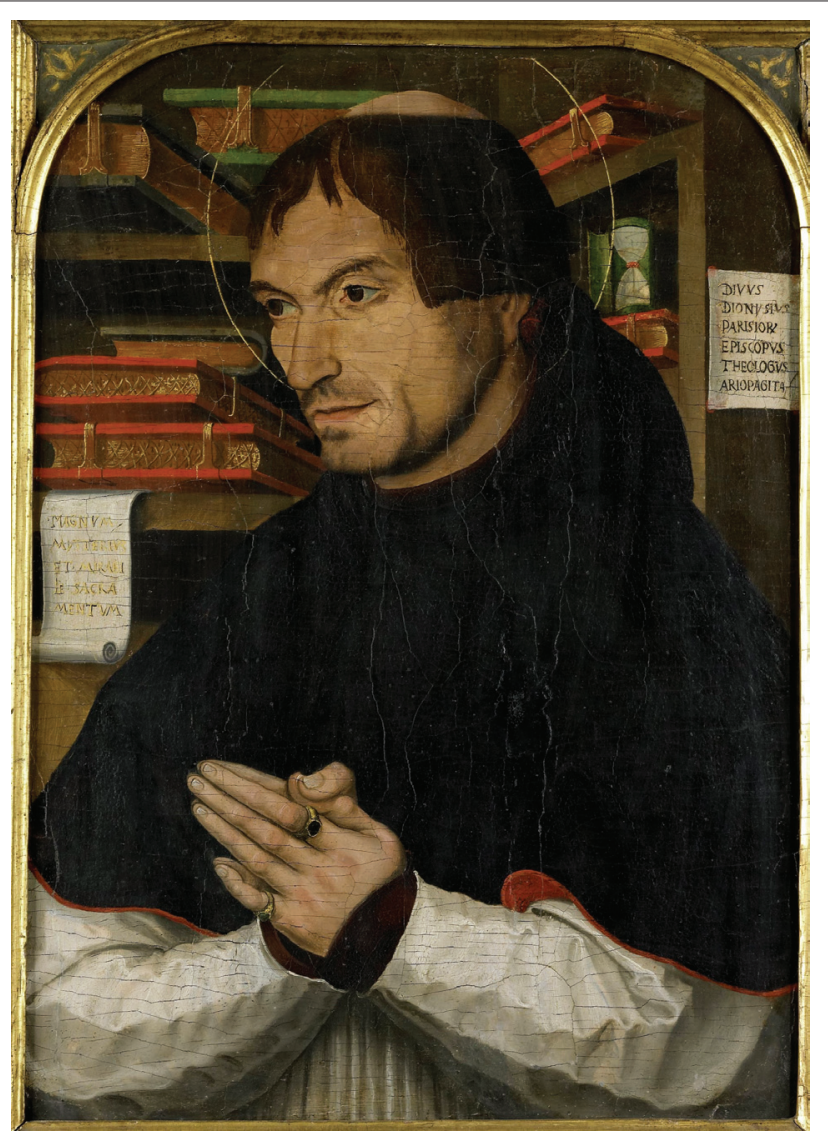

Bron: Anoniem, 1505-1510, De heilige Dionysius de Areopagiet in gebed, Rijksmuseum Amsterdam, viewed n.d, from https://nl.wikipedia.org/wiki/Bestand:De_heilige_Dionysius de_Areopagiet_in_gebed_Rijksmuseum_SK-A-3116.jpeg

FIGUUR 1: De heilige Dionysius de Areopagiet in gebed.

filosofie het steeds 'n grondige invloed op sowel Christene as nie-Christene uitgeoefen. In die skole van sowel Athene as Aleksandrië het studente steeds die Griekse tekste gelees, wat die Neoplatoniste Plotinus, Porphyreus en Proklus, ingesluit het. Hierdie Neoplatoniese tekste is op enkele uitsonderings nie in Latyn vertaal nie - dit moes uit die Griekse tekste gelees word. Daarom is die impak van Dionisius, as 'n Griekse denker en duidelik 'n Oosters-Bisantynse skrywer, op die Latynse Weste nie heeltemal onverwags of vreemd nie.

Dionisius se tekste is opgeneem in Corpus Dionysiacum (Pseudo-Dionisius 1990). Dit bestaan uit vermelde vier tekste en 10 briewe, uiteindelik in die negende eeu in Latyn vertaal as De Divinis Nominibus [Oor Goddelike name], De Mystica Theologia [Oor mistieke teologie'), De Coelesti Hierarchia [Oor die hemelse hiërargie], De Ecclesiastica Hierarchia [Oor die kerklike hiërargie] en Epistulae [Briewe]. Uit hierdie tekste tree enkele temas na vore wat tot so laat as in die 15e eeuse metafisika neerslag sou vind (sien Figuur 1).

\section{Die Middel-Platoniese en Neoplatoniese trajek by Dionisius}

Die vertrekpunt en eerste beginsel van Dionisius se filosofie is die weliswaar dogmatiese oortuiging dat God 'anderkant Syn' (hyperousios) is (Pseudo-Dionisius 1990: De Divinis 
Nominibus I4,593A). ${ }^{8}$ Dit beteken dat God die basis vir alle Synsvorme is, maar self nie Syn of 'n Synsvorm is nie, en daarom absoluut onkenbaar en onverwoordbaar is. Dionisius verskaf geen pertinente filosofiese regverdiging vir hierdie dogmatiese posisie nie, maar dit is onmiskenbaar Neoplatonies. Voordat ons egter oor Neoplatonisme as die primêre bron van Dionisius se metafisika kan praat, sou ons eers die Neoplatoniese resepsie van Plato (en tot ' $n$ mindere mate, Aristoteles) via Middel-Platonisme moet verreken.

Plato (428/7-348/7 v.C.) se Akademie het produktief in Athene bly voortbestaan tot deeglik die Christelike era in, maar as 'n filosofieskool het dit oor meer as vier eeue talle teoreties-posisionele veranderinge ondergaan (Dillon 1996:51-59). Gekonfronteer deur die filosofies-outentieke aansprake en uitdagings van die Stoïsyne (gestig deur Zeno, 495-430 v.C.; vgl. Tarrant 2011: XX23-XX37) en die Epikureërs (gestig deur Epikurus, 341-270 v.C.), het die Akademie in die geslag onmiddellik na Plato in skeptisisme en filosofiese agnostiek teruggetrek. Die Akademie in hierdie tweedegenerasie tydperk ná Plato het bekend gestaan as die 'Middel Akademie' of 'Tweede Akademie'. Die filosofiese disposisie van die Middel Akademie was apologeties, in die sin dat dit in hierdie ongeveer 150 jaar uitsluitlik besig was om Plato se filosofie te verdedig teen enersyds Aristoteles (384/3$322 / 1$ v.C.) en die Lyceum se filosofiese aanvegting van die wesenlike elemente van Plato se filosofie, maar ook juis teen ander opkomende filosofieë, soos Stoïsisme en Epikurisme.

Hierdie tydperk van apologetiese terugtrekking is uiteindelik tot ' $n$ nuwe kritiese tydperk vir die Akademie getransformeer deur Karneades van Sirene (214-129 v.C.), wat die Middel Akademie formeel tot die 'Nuwe Akademie' geherstruktureer het. Kenmerkend van die Nuwe Akademie was die filosofiese posisie van 'waarskynlikheid' as lewens- en handelingsweg. Hoewel aanvanklik 'n ondergewaardeerde teoretiese posisie, het dit in gewildheid toegeneem met die toetrede van die Romeinse skrywer, Cicero (106-43 v.C.). Natuurlik was Cicero se filosofiese invloed en erudisie beperk, in vergelyking met sy formidabele literêre uitset en korpus, maar nietemin het sy formele assosiasie met die teoretiese grondslae van die Nuwe Akademie impetus verleen aan die Akademie se voortbestaan tot diep die vroeg-Christelike era in.

Die Akademie het op hierdie stadium nie veel meer as 'n historiese band met Plato gehad nie. Op hierdie stadium was daar in so 'n mate 'n ontvanklikheid vir nuwe idees dat die outentieke Plato verskraal het onder die gewig van pogings om ooreenkomste tussen Plato en Aristoteles te vind en daarop te fokus, of selfs doelbewus gestreef is na 'n simbiose van Plato en Aristoteles se teoretiese posisies - uiteenlopend soos wat dit was. Daarby het ook die impulse vanuit Stoïsisme en Epikurisme, asook 'n herleefde Pythagorisme, gedien om 'n hibriede oorgangsfilosofie te ontwikkel, wat 'MiddelPlatonisme' genoem kan word..$^{9}$ Middel-Platonisme, juis as 'n

8.Die lengte van verwysings per Harvard na die primêre tekste van Pseudo-Dionisius (1990) werk steurend in op die vloei van die teks. Daarom word verwysings na die primêre tekste van Pseudo-Dionisius per eindnota hanteer.

9.Die term self is uiteraard ' $n$ moderne navorsingskonsep. hibriede filosofiese posisie, bestryk en omsluit 'n wye verskeidenheid denkers, nie slegs meer vanuit Athene nie, maar nou ook vanuit die ander groot Griekse sentrum, Aleksandrië. Juis omdat ons hier met 'n oorgangsposisie (vgl. Merlan 1967: $1-8)$ te make het, behoort periodisering soepel te wees, maar 80 v.C. - 220 dien in die literatuur as 'n gangbare merker (Dillon 1996:6). ${ }^{10}$ Hoewel daar ook versigtig met prinsipiële vertrekpunte binne só 'n hibriede konteks te werk gegaan behoort te word, is dit nie onverstandig om minstens enkele herhalende temas in Middel-Platonisme uit te wys nie.

By herhaling word die opvatting van nous, wat met 'verstand' vertaal kan word, in Middel-Platonisme aangetref (Dillon 1996:6). Die konsep van 'verstand' is kenmerkend van bogenoemde tydelike rekonsiliasie van Plato en Aristoteles, aangesien dit as 'n kombinasie van die idees van die Goeie by Plato en die Onbeweegde Beweger by Aristoteles aangebied is. Kenmerkend huiwer Middel-Platonisme nie om die Platoniese Vorme as bedink deur die verstand aan te bied nie, maar om 'n pertinente, gedefinieerde status aan die Vorme toe te skryf, wat natuurlik in die klassieke Platoniese weergawe ontbreek. Daar was egter ook'n toenemende aksent op die transendensie van verstand self, ten diepste ontleen aan die Pythagorasinvloed, en die verstand se relasie met die fisiese wêreld via intermediêre konsepte soos Logos [Woord], wat in die Nuwe Testament van die Christelike Bybel, waarvan al die tekste gedurende die hoogbloei van Middel-Platonisme geskryf is, ' $n$ deurslaggewende konsep is (Tarrant 2011:XII197-XII204).

Die belang van Middel-Platonisme vanuit Middeleeuse perspektief voltrek op minstens drie vlakke: eerstens verskaf Middel-Platonisme die belangrikste konsepte vanuit die Griekse filosofie, hoewel gedistilleerd ná die eise van die hibriede posisie, tydens die eerste twee eeue van die Christelike godsdiens. Die konseptuele en terminologiese effek van Middel-Platonisme - of dit nou direk geabsorbeer is en of dit nou (meer waarskynlik) deur Hellenistiese invloede op Judaïsme geïnkorporeer is - is onder andere duidelik in die Evangelie van Johannes. Dit het ook op daardie stadium reeds 'n diep merk gelaat op die denke van Filo van Aleksandrië (20 v.C. - 40; vgl. Dillon 1990:XI1-XI8), reeds behoorlik ingang gevind in Joodse teologie, en 'n bepalende invloed uitgeoefen op die denke van vroegChristelike teoloë, veral Clemens van Aleksandrië (ca. 150215) en Origenes (184-254; vgl. Haren 1985:30 ev.).

Tweedens het die navorsing en teoretisering vanuit MiddelPlatonisme direkte bydraes gelewer tot die bronne van Middeleeuse filosofie: byvoorbeeld, Calcidius se invloedryke vertaling van Plato se Timaeus uit Grieks na Latyn (wat die enigste omvangryke teks van Plato beskikbaar in die Latynse Weste vir die volgende 800 jaar sou wees; vgl. Gersh 1986:421492), asook Calcidius se kommentaar op die teks, staan baie nader aan Middel-Platonisme as aan latere ontwikkelinge, ${ }^{11}$ hoewel dit waarskynlik in die middel van die vierde eeu

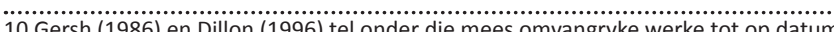
oor Middel-Platonisme as sodanig. Dillon se verantwoorde periodisering van Middel-Platonisme, 80 v.C.-220, word ook hier gebruik.

11.Dit sluit Macrobius (Dillon 1986:493-596), Martianus Capella (Dillon 1986:597646) en Marius Victorinus (Gersh 1986:719-729) in. 
geskryf is, toe Middel-Platonisme reeds plek gemaak het vir Neoplatonisme (vgl. Wagner 2008:275-288).

Derdens was Middel-Platonisme juis die onmisbare voorloper tot Neoplatonisme, wat'n ongeëwenaarde invloed op Christelike teologie in die laat-patristiek en vroeë Middeleeue gehad het. Neoplatonisme het trouens die vroegMiddeleeuse perspektief op Platonisme grondig bepaal, asook die wyse waarop Aristoteles in die vroeg Latynse Weste ontvang is.

'Neoplatonisme' verwys gevolglik na 'n filosofiese stelsel wat, met inbegrip van hierdie Middel-Platoniese erfenis, gekonstrueer is deur die Griekse skrywer Plotinus (204-270), asook die verwerking van daardie stelsel deur Plotinus se opvolgers, in besonder Porphyreus (ca. 234 - ca. 305) Plotinus se onmiddellike opvolger - maar ook minstens Amelius (fl. 259), ${ }^{12}$ Eustochius (fl. 260), Serapionus (fl. 260), Castricius Firmus (fl. 250), Iamblichus (ca. 245 -ca. 325), en later ook Macrobius (fl. 400), Martianus Capella (360-428) en Marius Victorinus (fl. 355) (Gersh 1986:421-729).

Plotinus is in Egipte gebore en het sy intellektuele ${ }^{13}$ opvoeding te Aleksandrië ondergaan. Later, vanaf ca. 244, het hy in Rome - in 'n tyd van enorme staatkundige onrus deur die hele Romeinse Ryk heen (vgl. O'Meara 1995:4) - onderrig gegee en ' $n$ klein vereniging gestig wat in besonder gemoeid was met 'n kritiese en oorspronklike herlesing van Plato se tekste, asook met ' $n$ herwaardering van die ander erfenisse vanuit die $\mathrm{Ou}$ en Middel Akademie. Porphyreus was verantwoordelik vir die redigering en sistematisering van Plotinus se geskrifte, wat uiteindelik in ses volumes van nege

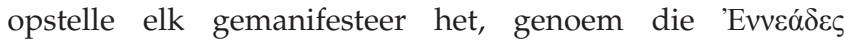
(Enneades; letterlik die Nege's).

Hoewel Porphyreus die ontwikkelingsgeskiedenis en die chronologie van die 54 tekste goed geken het, het hy dit juis tematies georganiseer. Die eerste drie Enneades fokus op die immanente: Enneades I handel oor die mens en etiek, Enneades II oor die fisiese werklikheid, en Enneades III oor filosofiese probleme rakende die wêreld, waaronder noodlot, die voorsienigheid, ewigheid en tyd. Enneades IV hanteer Plotinus se leer oor die Siel, Enneades $V$ die Verstand, en Enneades VI Syn en die 'Een'. ${ }^{4}$

Plotinus se denke wentel rondom twee prinsipiële temas: Oorsprong en Voleinding; 'vanwaar' en 'waarheen (terug)'. Die Enneades is 'n beskrywing van die 'afstygende' oorsprong van dinge vanuit eenheid en volmaaktheid, na 'n 'opstygende' ${ }^{15}$ meervoudigheid. Die kenmerkende Middel12.Amelius het 'n notariërende kommentaar van 100 volumes oor Plotinus nagelaat
(O'Meara 1995:1).

13.Vgl. Armstrong (1962:11-15); O'Meara (1995:1-10); Gerson (1994:xii-xiv).

14.Plotinus se aanbod van hierdie konsepte word normaalweg met hoofletters uit die Grieks vertaal, na die aksent van uniekheid wat Porpyhreus self daarop geplaas het, ter wille van ' $n$ onderskeid van ' $n$ aanbod van dieselfde konsepte vanuit ander vertaal word, in onderskeid met die Aristoteliese 'vorme'; sien ook Armstrong (1962:18).

15 Dit sal weldra duidelik word wat met 'afstyging' en 'opstyging' bedoel word.
Platoniese poging om die werklikheid aan die hand van 'n transendente beginsel te voltrek, word deur Plotinus in die logiese konsekwensies daarvan deurgevoer. Die transendentale nous [verstand] wat so sentraal gestaan het in MiddelPlatonisme, word deur Plotinus as ontoereikend getipeer, omdat die denke en die objek van denke steeds onderskeibaar is en dus nie 'n finale transendente begrip van eenheid kan postuleer nie. Daarom stel Plotinus ' $n$ beginsel wat vir hom die hoogste vorm van enkelvoudigheid en onverdeelbaarheid verteenwoordig, naamlik (die) 'Een'. Die enkelvoudigheid, eenvoudigheid en suiwer transendensie van die Een oorstyg enige kategorisering, wat beteken dat die Een onder geen omstandigheid 'n predikatiewe subjek kan wees nie; met ander woorde, die Een kan nie aan die hand van enige een of meer van Aristoteles se tien praedicamentae verklaar of verstaan word nie. ${ }^{16}$

Maar daarby geld 'n leerstelling wat teruggaan na Parmenides en wat deur Plato se hele oeuvre herkenbaar is, naamlik dat 'om te wees, is om verstaanbaar te wees'. Wat is, kan verstaan word. Wat nie verstaan kan word nie, 'is'-nie, met ander woorde, is anderkant Syn. Daarom handel Plotinus se nadenke oor die Een onafwendbaar oor die implikasies van die Een en poog hy nie om die Een se aard of natuur te verken nie. Dit beteken egter nie dat Plotinus se konsep van die Een ontdaan is van 'n positiewe inhoud nie. Plotinus se werklikheidsbegrip sentreer rondom die produktiewe kwaliteit van die Goeie, waarvan die Een juis die absolute verteenwoordiging is. Daarom word die 'Een' (to hen) en die 'Goeie' (to agathon) konseptueel uitruilbaar gebruik (vgl. O’Meara 1995:8).

Plotinus werk met drie hypostases: die Een, die Verstand en die Siel. Vanuit die Een word 'n potensialiteit vir Syn - die materie van intelligente lewe - gegenereer, in afstygende orde. Die eerste Syn is Verstand (nous), wat die eenvoudigheid en enkelvoudigheid van die Een repliseer, maar reeds nie meer die eenheid van die Een kan repliseer nie. Die Verstand bemoontlik direk en ewig alles wat verstaanbaar is: alle vorme van die werklikheid, insluitende die vorme van individuele Syn. Die Verstand produseer nie die vorme deur die vorme te 'bedink' nie. Die vorme is reeds die natuur van die Verstand en deur die vorme te ken, ken die Verstand sigself, in ooreenstemming met die Aristoteliese beginsel dat denke en die objek van denke identies is. Op hierdie wyse behou Plotinus die objektiwiteit van die vorme, terwyl die vorme binne die stelsel van 'afstygende generering' of 'emanasie' ${ }^{17}$ geïnkorporeer word.

$16.1 n$ Categoriae argumenteer A praedicamenta, die antepraedicamenta, 'n vierledige struktuur behels, wat self ontstaan vanuit twee basiese spraakvorme, of spraak-as-syn, naamlik eenvoudig (bv. 'die vrou') of kompleks (bv. 'die vrou loop'), terwyl slegs laasgenoemde komplekse spraakvorme waar of vals kan wees. Vanuit alle dinge wat bestaan, is (1) sommige dinge predikate van ' $n$ subjek, maar nie teenwoordig in 'n subjek nie; (2) sommige dinge in 'n subjek, maar nie predikate van 'n subjek nie; (3) sommige dinge in sowel 'n subjek as 'n predikaat van die subjek; en (4) sommige dinge nie in 'n subjek of in enige predikate van die subjek nie. Die tien praedicamenta val voorwaardelik op die antepraedicamenta terug. Die eerste is Ousia / Substantia (of tode ti of ti esti - substansie, 'dit' of 'wat dit is'), wat nie gepredikeer kan word ten aansien van enige objek nie en wat nie 'in' enige objek is nie (bv. 'vrou', 'Dolores', 'Dolores is ' $\mathrm{n}$ vrou'); gevolg deur die nege ander praedicamenta.

17. Die begrip 'emanasie' dui Plotinus se bedoeling aan met die afstygende produksie van Syn vanuit die Een na Verstand na Siel en die laer dinge (sien Armstrong 1937:63). Tog is emanasie self ' $n$ metafoor vir die onbedinkbare eerste beweging $1937: 63)$. Tog is emanasie self ' $n$ metafoor vir die onbedinkbare eerste beweging
vanuit die Een en kan ' $n$ taalkundig meer verbuigbare en soepeler begrip soos

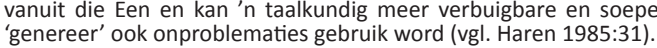


Soos wat die Verstand deur die Een gegenereer is, genereer die Verstand die beginsel van die Siel ( $p s u c h e$ ). Duidelik oorgeneem uit Plato se Timaeus, is die Siel die 'brug' tussen die intellektuele en sintuiglike wêrelde. Juis omdat dit 'n brug is, beskik die universele Siel na Plotinus se analise oor twee kante. Die eerste, hoër kant van die Siel soek opstygend 'n verstaan van die Verstand op, terwyl die tweede, laer kant die beginsel van orde in die materiële wêreld (Natuur) is, wat deur afstyging of emanasie die vorme wat reeds bevat is in die Verstand, herproduseer. Die vorme van liggaamlike dinge is die individuele siele wat oor dieselfde tweeledige karakter van die universele Siel beskik. In die afstygende emanasie vanaf die Een, is materie die laaste en verste limiet van die werklikheid. Materie is suiwer potensialiteit vir vorming, maar is intrinsiek leeg - dit is eers wanneer dit uit 'be-sieling' 'ge-vorm' word, dat materie 'word'. Daarom staan Plotinus agterdogtig teenoor materie: omdat dit leeg is, het dit ook 'n stollende effek op die siel. Materie, as die laaste Syn, wat die laagste emanasie vanuit die Verstand is, verdonker die ware karakter van die siel. Bevryding van materiële verknooptheid en kosmiese opstyging na die hereniging met die Verstand, is daarom die siel se hoogste aspirasie.

Vir die doeleindes van 'n terugkoppeling met Neoplatonisme vanuit die latere Middeleeue, is dit noodsaaklik om te beklemtoon dat Porphyreus nie bloot 'n redakteur van sy meester Plotinus se geskrewe werke was nie, hoewel dit ongetwyfeld sy mees vername diens aan Neoplatonisme was. Porphyreus se eie werke was ook invloedryk: sy inleiding (Isagoge) tot Aristoteles se Categoriae is 'n voorbeeld van die noukeurige woord-vir-woord kommentaar wat die skolastiese werkswyse eeue later so bepalend sou kenmerk. Boonop sou Porphyreus se interesse in Aristoteles, Boethius (ca. 477 - 524) se deurslaggewende Latynse vertaling van en kommentaar op Aristoteles daadwerklik lei. Die Isagoge is trouens in die Middeleeue as 'n standaard kommentaar op die Organon gebruik en was indirek verantwoordelik vir die vertrekpunte van die vroeg-Middeleeuse debatte oor die status van universeles. Maar selfs belangriker, heelwat van Porphyreus se eie geskrifte (waarvan die meerderheid verlore geraak het) was beskikbaar vir Augustinus, en Augustinus het eerder Porphyreus as Plotinus self gebruik om die Neoplatoniese posisie te verhelder (Armstrong 1962:45-48).

Porphyreus se eie werk verteenwoordig 'n opsetlike poging om die mistiese en dikwels ambivalente kwaliteit van Plotinus se denke, te vereenvoudig. Porphyreus was veral geneig om die onderskeid tussen die Verstand en die vlakke of kante van die Siel te reduseer, en die dualisme van siel en materie te beklemtoon. In daardie sin was hy eksplisiet nuut-Platonies. Porphyreus het ook baie sterker tot polemieke gedurende die hoogbloei van Neoplatonisme toegetree as Plotinus self. Dit is nie seker of Porphyreus bekend was met dogmatiese verwikkelinge in die Christendom nie, hoewel hy skerp uitgesproke was teen die gnostiek waarmee die Christendom op daardie stadium geassosieer is. Daarby het Porphyreus hom beywer vir die herwinning van pagaanse religie, wat 'n pertinente kenmerk van die laaste fases van die beweging was.
In Aleksandrië het die oorspronklike taakstelling van Neoplatonisme voortgegaan, maar met toenemende klem op Aristoteles. In teenstelling met die Neoplatoniese ontwikkelinge in Rome, wat toenemend misties-pagaanse afmetings aangeneem het, het die Aleksandrynse Skool gefokus op die voortsetting van die herlesing en kommentariëring van die uitsette van die Ou en die Middel Akademie, terwyl besondere aandag aan Aristoteles se logika gegee is. Dit was juis die 'ou skool' Neoplatonisme wat in Aleksandrië bedryf is, wat Augustinus, as die 'eerste Middeleeuse filosoof'18 toegang sou gee tot 'n antieke filosofiese erfenis van - op daardie stadium - digby agt eeue.

\section{Dionisius se Neoplatoniese metafisika}

By Plotinus en Porphyreus tref ons dus die Neoplatoniese leerstelling aan rondom die Een, wat die eerste beginsel van die werklikheid is, anderkant Syn en kennis, met die gelyklopende leerstelling dat 'om te wees, is om verstaanbaar te wees'. Dit bevestig dat wat ook al is, bedinkbaar is; verstaanbaar vir die verstand. Dit sou onmoontlik wees om 'n Syn te postuleer wat nie bedink kan word nie, aangesien só 'n postulering reeds aankom op 'n bedinking van die Syn. Verstaanbaarheid, dit wat deur die verstand begryp kan word, is in hierdie sin die wesenlike betekenis van Syn. Syn is daarom in Neoplatoniese sin definitief en begrensd; alleen maar 'n definitiewe en begrensde 'dit' kan deur die verstand begryp word. Enige Syn bestaan daarom in die gedetermineerde totaliteit van die eienskappe of attribute van daardie Syn, waarom dit is wat dit is, en juis daarom begrypbaar is.

In Neoplatoniese sin kan die eerste beginsel van die werklikheid daarom nie enige Syn wees nie. As dit die geval sou wees, sou die eerste beginsel self begrensd wees en self gedetermineer wees deur die eienskappe daarvan. Verder sou die eerste beginsel in effek minstens een eienskap met alle ander Synsvorme deel, naamlik die Syn self. Dit sou dan net een deel van die totaliteit van dinge uitmaak, eerder as om 'n bron van daardie totaliteit van dinge te wees. Die gedeelde eienskap Syn sou dan as voorafgaande tot die veronderstelde eerste beginsel en alle ander dinge wees. Daarom plaas Neoplatonisme soveel nadruk daarop dat die bron van alle dinge nie enige Syn of 'n ander objek van die denke kan wees nie, maar dat die bron of eerste beginsel

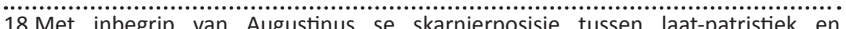
Middeleeuse filosofie, wat 'n netelige periodiseringsprobleem in Middeleeuse filosofie bly (vgl. Beukes 2011:1; 2012:1). Die outeur se sesdelige periodisering van Middeleeuse filosofie kom in kort op die volgende neer: (1) Die post-Romeinse Middeleeuse filosofie kom in kort op die volgende neer: (1) Die post-Romeinse
periode - vyfde tot sewende eeue (410 [Alaricus I en die eerste barbaarse inval in periode - vyfde tot sewende eeue (410 [Alaricus I en die eerste barbaarse inval in
Rome] tot 668 [dood Konstans II]), met Augustinus (354-430) en Boethius (480524) as die belangrikste filosofiese eksponente; (2) Die Karolingiese periode agtste en negende eeue (742 [geboorte Karel I] tot 877 [dood Eriugena]), met Alcuin (730-804) en Eriugena (815-877) as die belangrikste Latyns-Westerse geleiers van die Karolingiese Renaissance, met inbegrip van die opkoms van Arabiese filosofie in die Ooste en Spanje; (3) Die post-Karolingiese periode negende tot $12 \mathrm{e}$ eeue ( 877 [dood Eriugena] tot 1088 [aanvang van die kruistogte en die opkoms van die vroegste universiteitswese]), met Anselmus (1033-1109) en Abelardus (1079-1142) as die mees gevolgryke onder die Latyns-Westerse denkers Abelardus (1079-1142) as die mees gevolgryke onder die Latyns-Westerse denkers wat sou baat by die rehabilitering van die antieke erfenis in die Karolingiese Renaissance; (4) Die vroeë-skolastiese periode - 11e tot 13e eeue (1088 [stigting van die Universiteit van Bologne, die eerste Europese universiteit] tot 1225 [geboorte Aquinas]); (5) Die hoog-skolastiese periode - 13e tot 1 e eeue (1225 geboorte $A$ uinas tot 139 dood O kham, met A uinas, Duns Skotus en Ockham as die beroemdstes onder die ho skolasti i); (6) Die post-skolastiese periode - 14e to $15 \mathrm{e}$ eeue (1349 [dood Ockham] tot 1464 [dood Kusa]). 
hyperousios is. Hierdie opvatting verskaf die argumentatiewe vertrekpunt vir Dionisius se werk en is latent teenwoordig deur sy oeuvre.

Wanneer Dionisius God postuleer as hyperousios, beteken dit nie dat oor God dan slegs in terme van negatiewe stellinge gepraat kan word nie; met ander woorde, dat slegs negatief gepostuleer kan word dat God is nie of God is onkenbaar; vir die rede dat negatiefstelling of negasie steeds 'n denkhandelende aktiwiteit is en as sodanig God steeds, hoewel in die negatief, konseptualiseer. In daardie sin is daar geen korrektiewe verskil tussen God is en God is nie - om God se bestaan of enige attribuut van God te negeer, beteken om God steeds as gekonseptualiseerde objek te hanteer; hetsy enersyds in besit van of andersyds ontdaan van bepaalde attribute. Om te postuleer God is onkenbaar beteken effektief om God te identifiseer as 'n onkenbare wese en maak dus wel aanspraak op kennis van God, hoe minimaal ook al. Daarom stel Dionisius dat God 'anderkant elke negasie en affirmasie'19 is. God is nie bloot onverwoordbaar en onkenbaar nie, maar is 'anderkant onverwoordbaarheid en onkenbaarheid'.$^{20}$

'Negatiewe teologie' beteken vir Dionisius, soos sy Neoplatoniese voorgangers, nie robuuste negasie nie, maar 'stilte' en 'stilwording'; om die 'verskuildheid van die Goddelike, anderkant verstand en Syn' met 'n 'gewyde en daarom wyse stilte' te eerbiedig. ${ }^{21}$ Die verstand se eenwording met God kan slegs gebeur met die 'opskorting van elke intellektuele onderneming'. ${ }^{22}$ Die stilte self is nie ' $n$ vorm van kennis nie, maar juis die 'nie-gebeure' van kennis; kennis as 'nonaktiwiteit'. ${ }^{23}$

Dionisius se opvatting van stilte is nie 'n soort mistiese verdamping nie, maar moet verstaan word as 'n deeglike, filosofiese deduksie vanuit die verstaanbaarheid van Syn. Wanneer God iets is of nie iets is nie, wat dus affirmerend of negerend deur die verstand begryp kan word, is dit nie meer God of Skepper nie, maar 'n begrensde skepsel wat aan die orde is. Enige intellektuele onderneming is gerig op die bevatlikheid van een of ander Syn, en daarom van die een of ander begrensde skepsel - nie die bevatlikheid van God of Skepper nie.

Die vraag ontstaan of daar vanuit hierdie Neoplatoniese gerigtheid hoegenaamd oor God gedink en gepraat kan word, anders as om terug te trek in stilwording. Dionisius se antwoord is dat ons wel oor God kan praat, in die sin dat ons God kan benaam of ken vanuit alle geskepte dinge, dit is alle Syn, as die oorsaak van daardie dinge of Syn. ${ }^{24}$

19.Pseudo-Dionisius (1990: De Mystica Theologia 1.2,1000B; v,1048B); vgl. Rorem (1993:3-38)

20.Pseudo-Dionisius (1990: De Divinis Nominibus 1.4,592D); vgl. Sheldon-Williams (1967:457-472).

21.Pseudo-Dionisius (1990: De Divinis Nominibus I.3,589AB); vgl. Rorem (1993:3-38).

22.Pseudo-Dionisius (1990: De Divinis Nominibus I.4,593 C; 1.4,592CD); vgl Rorem (1993:3-38) en Sheldon-Williams (1967:457-472).

23.Pseudo-Dionisius (1990: De Mystica Theologia I.3,10001 A; III.1,1033C); vgl Rorem (1993:7).

24.Pseudo-Dionisius (1990: De Divinis Nominibus I.5,593 AB; I.5,593D; I.6,596A; De Coelesti Hierarchia IV.1,177D); vgl. Bosley en Tweedale (2004:547-555).
Op die oog af beteken die aanduiding 'oorsaak' wel weer 'n identifisering van God as Syn, begrensd en verstaanbaar. Dionisius gebruik die begrip 'oorsaak' egter bepaald Neoplatonies: aangesien 'is' of 'om te wees' beteken om determineerbaar te wees, is enige wese of Syn vir die bestaan daarvan afhanklik van die gedetermineerdheid daarvan, sodat die gedetermineerdheid daarvan die oorsaak van die wese of Syn is. God is die Skepper van alle dinge, as die konstituerende determineerder van alle dinge, wat elke ding determineer om te wees deur dit te maak 'wat dit is'. God is sodoende die Synheid van alle Syndes, sonder dat God self Syn is. ${ }^{25}$ Die Synheid van alle Syndes is die oorsaak van en bepalend vir elke Syn; die lewe van alle lewende dinge waardeur die dinge lewe, 'alle dinge in alle dinge'. ${ }^{26}$ Alle determineringe en volkomenhede van alle dinge, die totale inhoud van die skepping, het God kreatief in-sig-self. God kan dus benaam of geken word, maar slegs in soverre God kousaal teenwoordig is in alle wesens, in alle Syn.

Met hierdie Neoplatoniese opvatting van die skepping as determinering word die moontlikheid dat God, as oorsaak, gemaak word tot bloot 'n ander wese naas God se skepsels, gesystap - God is nie hoogste Syn nie, maar die Synheid van alle Syndes; in daardie sin alle Syn en geen-Syn; ${ }^{27}$ 'alle dinge in alle dinge en niks in enige ding nie'. God is 'alle dinge in alle dinge' in die sin dat die werklikheid die gedifferensieerde teenwoordigheid van God is; en 'niks in enige ding' nie, in die sin dat God self nie enige ding is nie. God is tegelyk radikaal transendent en radikaal immanent: transendent in die sin dat God self nie enige wese of Syn is nie; immanent, in die sin dat God onmiddellik teenwoordig is voor alle dinge as die Synheid van alle dinge. God is die toevouer van alle dinge en alle dinge is die oopvouer van God. God 'voorbehou' so alle dinge in Godself sonder onderskeid. ${ }^{28}$ God is gedifferensieerd teenwoordig voor alle dinge en laat die dinge 'dinge wees'. God is self nie 'n gedifferensieerde Syn nie, maar die pertinente differensieerder op sterkte waarvan elke skepsel 'is' en 'is wat dit is'. Dionisius verstaan skepping dus as differensiasie; in daardie sin as 'teofanie', ${ }^{29}$ die manifestering van God; die Goddelike 'Niks' word geken in alle dinge as hulle gedifferensieerde volkomenhede.

Die skepping of werklikheid self word deur Dionisius as 'hiërargies' ${ }^{30}$ verstaan, in terme van die verhouding tussen skepsels en God. Daar bestaan vir Dionisius nie 'n reeks of prosessie van kwasi-goddelike veelvoudighede, gemedieer in die skepsels, nie, maar eerder Godself wat teenwoordig voor en voorwaarde vir elke skepsel is.. ${ }^{31}$ Daarom praat Dionisius van die 'Goddelike Name' teenwoordig voor die 25.Pseudo-Dionisius (1990: De Divinis Nominibus V.4,817C,817D).

26.Pseudo-Dionisius (1990: De Divinis Nominibus 1.3,589C, 1.7,596C).

27.Pseudo-Dionisius (1990: De Divinis Nominibus I.6,596C).

28.Pseudo-Dionisius (1990: De Divinis Nominibus 1.7,597A).

29.Perl se aanbod (2007:17-34; 2006:541-544); vgl. ook Haren (1985:75-77); Marenbon (1988:18-20).

30. Hyman et al. (2010:141-144); Luscombe (1997:23-29); Perl (2006:545-547; 2007:65-82).

31.Pseudo-Dionisius (1990: De Divinis Nominibus V.2,816 C; XI.6,953C). 
skepsels, wat hy hiërargies orden in terme van die universaliteit daarvan. Die Goeie, as eerste Naam, is die hoogste in die hiërargie, omdat God as Goedheid in alle wesens teenwoordig is. Syn is die tweede Naam, omdat Syn teenwoordig in alle Syn of wesens is, lewend of bloot in materie. Lewe is die derde Naam, omdat dit teenwoordig is in alle lewende wesens. Wysheid is die vierde Naam, omdat dit teenwoordig is in alle kognitiewe lewende wesens. ${ }^{32}$

Die orde van die Goddelike Name reflekteer, asof in 'n spieël, die orde van skepsels: die Goeie > materie; Syn > wesens; Lewe > lewende wesens; Wysheid > kognitiewe lewende wesens. Die laer name word by die hoër name ingesluit op grond van hulle spesifikasies, sodat niks 'n hoër naam kan dra sonder om ook die laer name in te sluit nie. Lewende wesens, wat lewe, het reeds ook Syn. Kognitiewe lewende wesens, wat kognitiewe vermoë het, het reeds ook Syn en reeds ook lewe. Trouens, die hoër en laer name is modi van dieselfde Goddelike teenwoordigheid wat alle dinge konstitueer. Denke byvoorbeeld, is die hoër modus van lewe, terwyl Syn die laer modus van lewe is.

Hierdie progressiewe spesifisering in Dionisius se hiërargie lei tot die gedetermineerde bepaling of logoi van partikulieres, op grond waarvan elke individuele skepsel 'sigself is' en daarom 'is'. Hiermee ontplooi Dionisius 'n eie weergawe van die Aristoteliese vorme, of 'vorme van partikulieres', wat hulle spesifikasies aan die meer universele Vorme ontleen: God is sodoende teenwoordig voor elke ding en elke ding partisipeer analogies in God in ooreenstemming met die plek daarvan op die partikulariserende hiërargie. God is voor elke ding in die spesifieke modus van daardie ding en konstituerend van daardie ding.

Daar is vir Dionisius geen konflik tussen die hiërargiese ordening van die skepping, en die onmiddellike en onbemiddelde teenwoordigheid van God voor alle dinge nie. Elke skepsel partisipeer analogies maar direk in God juis deur die aangewese plek daarvan in die hiërargie van Syndes in te neem. Omdat God nie enige Syn is nie, staan God nie bo aan die hiërargie nie, maar transendeer die hiërargiese geheel en is tegelyk versprei deur die hiërargiese geheel.

Indien God dan die hiërargiese geheel transendeer, wat maak Dionisius se leser met die Middeleeus-hardnekkige vraag na 'boosheid'? Dionisius hanteer boosheid kenmerkend langs dieselfde lyne as Augustinus. Boosheid is nie 'n affirmeerbare attribuut nie, maar die ontdaning van die Goeie in 'n bepaalde Synspostulaat. Alle wesens, in soverre hulle is, is goed en vanuit die Goeie; en in soverre hulle ontdaan is van die Goeie, is hulle nie goed nie en is hulle nie. ${ }^{33}$ Net soos Plotinus, verwerp Dionisius die opvatting dat die stoflike of materie boos is of die oorsprong van boosheid kan wees. Boosheid vestig eerder in die gebrek van enige wese om die voor Synheid van alle Syndes gekonstitueerde aard daarvan, te volvoer en om inderdaad ten volle te wees. Omdat die

32. Pseudo-Dionisius (1990: De Divinis Nominibus V.1,816B).

33.Pseudo-Dionisius (1990: De Divinis Nominibus IV.20,720B) goedheid en Syn van elke wese beteken dat dit tot die Synheid van alle Syndes in stilte wil terugkeer, beteken boosheid dat die wese in gebrek bly om tot God te keer; daar is trouens 'n liefdesgebrek jeens God. ${ }^{34}$ Dionisius vertoef dus binne die Platoniese beginsel dat alle aktiwiteit gemotiveer word deur ' $n$ begeerte na die goeie, en uiteindelik na God, as die Goedheid van alle dinge. Daarom is selfs op die oog af bose handelinge - wat byvoorbeeld uit wellus of woede spruit - steeds gerig op die goeie in die een of ander sin: indien dit nie steeds op die goeie gerig was nie, sou dit nie kon wees nie. Indien die handeling wel eksplisiet die bose begeer, begeer dit niks, en hou die wese op om te wees. Boosheid kan daarom nie 'n positiewe, affirmerende handeling wees nie - dit begeer Niks en is daarom niks.

Dit bring ons dadelik by twee dringende kwessies, naamlik wat 'Wysheid' presies in hierdie hiërargie beteken, asook wat presies daardie 'analogiese deelname' van skepsels in die hiërargie inhou. Wysheid is vir Dionisius die onderskeidende volkomendheid van alle kognitiewe wesens (vir hom, engele, mense en diere). Dionisius onderverdeel wysheid in intellektualisering ( $>$ engele), die diskursiewe rede ( $>$ mense) en sintuiglike waarneming ( $>$ diere). Hierdie is weereens nie drie verskillende fakulteite met drie veronderstelde objekte nie, maar hoër en laer modi van werklikheidsbegrip, waar die hoër modus die laer modi reeds insluit. Dionisius werk hier implisiet met Proklus se leerstelling dat wat ook al geken word, word geken vanuit die modus van die kennende subjek en nie die modus van die gekende objek nie. Só 'ken die engele die dinge op aarde, nie deur dit te ken deur sintuiglike waarneming nie - hoewel die dinge sintuiglike dinge is - maar deur die gepaste naam vanuit die hoërvorm intellek'. ${ }^{35}$ Die modi van kenbaarheid word eg Neoplatonies onderskei in terme van die eenheidsgreep daarvan op die werklikheid, gegewe die plek daarvan op die kennislerige hiërargie. Intellektualisering het in termevan'n eenheidsgreep op die werklikheid die hoogste plek, terwyl sintuiglike waarneming die laagste plek het - maar selfs sintuiglike waarneming 'eggo steeds wysheid'. ${ }^{36}$

Soos wat die siel opstyg vanaf sintuiglike waarneming na diskursiewe rede na intellektualisering, neem die bevatlikheid daarvan tot 'n groterwordende eenheidsgreep toe, tot daar waar intellektuele kennis oorgaan in die stilte van eminensie. Dit is die siel se hoogste, weliswaar 'mistieke' unifikasie met God, in nie-kennende stilte. Die unifikasie met God is nie teenoorstaande die verstand of intellek se kognitiewe funksies nie, maar die hoogste doel en uitdrukking daarvan. Daar is ook geen opposisie tussen sintuig en intellek nie, omdat hulle hoër en laer modi van dieselfde kennende aktwiteit is, naamlik die bevatlikheid tot ' $n$ eenheidsgreep op die werklikheid.

Die 'analogiese deelname' van skepsels in die hiërargie dui op'n belangrike onderstroming in Dionisius se werk, naamlik

34.Pseudo-Dionisius (1990: De Divinis Nominibus IV.34,733C).

35.Pseudo-Dionisius (1990: De Divinis Nominibus VII.2,869C).

36.Pseudo-Dionisius (1990: De Divinis Nominibus VII.2,868C). 
simbolisme; by Dionisius tot op die punt van nadruk dat dit 'n soort proto-semiotiek word. Aangesien God nie 'n objek van enige kennende handeling is nie, synde die Synheid van alle Syndes en nie hoogste Syn nie, alleen 'kenbaar' deur die name in begrensde Syndes of skepsels, kan God alleen deur simbole geken word, wat die Goddelike Name in elk geval is. Enige nie-simboliese kennis sou noodwendig die kennis van die een of ander Synde moet wees; nie kennis van God nie. Simbole bring God tot uitdrukking, maar is nie God self of iets van Godself nie. Die simbool bring God voor die gesig en laat God dadelik agter, dit ontbloot en hersluier - en maak God op hierdie wyse kenbaar sonder om God tot Syn te objektiveer. Alleen in 'n simbool kan God ontmoet word sonder dat God se ontoeganklikheid ondermyn word, en daarom kan die ware Goddelikheid van God slegs in simboliek ontmoet word. Hierdie tweeledige funksie van simboliek, sowel ontblotend as hersluierend, word deur Dionisius met die begrip probeblesthai tot uitdrukking gebring; 'n woord wat sowel 'gee' of 'presenteer' as 'skild' kan beteken (vgl. Haren 1985:75-77; Perl 2006:547). Simbole is presentasies sowel as skilde van God en daarmee saam die presentasies en skilde van die totale Synsorde. ${ }^{37}$ In 'n semiotiese dialektiek is simbole vir Dionisius presentasies wat (be)skerm en skilde wat nietemin presenteer. Dionisius verstaan simbole op hierdie dialektiese wyse as ons enigste 'toegang' tot die ontoeganklike God. Daarmee word ook die kenmerkende jukstaposisie van transendent en immanent in Dionisius se Godsbegrip en werklikheidsbegrip, geaksentueer.

\section{Implikasies van die Dionisiese spoor vir die latere Middeleeuse filosofie}

Wat sou die betekenis van Dionisius se subtiele metafisika vir die latere Middeleeue wees? Daar is reeds genoem dat hy tematies in Skotus Eriugena (815-877) en Aquinas (1225-1274) se werk sou herverskyn, en dat dit welbekend en goed geboekstaaf is in die nisnavorsing (vgl. bv. die navorsingsoorsig van O'Rourke 1992:1-16 t.o.v. beide Eriugena en Aquinas). Dit is egter ook die geval by Meister Eckhart (ca. 1260-1328) en, hoewel volledig onderontgind, die 'laaste Middeleeuse filosoof', Nikolaus van Kusa (14011464), wat in die opvolgartikel (Beukes 2018) as eksemplaries van Dionisius se nawerking in die latere Middeleeuse filosofie gebruik word, in terme van Kusa se metafisika. Dionisius was egter ook die belangrikste informant van die inhoud van 'n filosofies meer gesofistikeerde aanbod van Neoplatonisme as wat by Augustinus aangetref word, ${ }^{38}$ en die belangrikste kanaal vir die vloei van Neoplatonisme na wat weldra sou uitkristalliseer as 'hoofstroom Middeleeuse filosofie' (Beukes 2011:13).

In bostaande oorsig is daar temas aangeraak wat aanwysbaar weer in die post-skolastiese periode weerklank sou vind, lank ná en buite-om Aquinas: die radikale transendensie en

\section{Pseudo-Dionisius (1990: De Divinis Nominibus V.5,820A)}

38. Moontlik 'n aanvegbare stelling, maar vergelyk O'Rourke (1992:3-21); Per (2006:548); Sheldon-Williams (1967:457-472). tegelyk radikale immanensie van God, God as Synheid, fundamentele taalbegrensdheid in die spreke oor God, die aanspraak van transendenteles, veral Goedheid en Syn, die skepping as 'n stelsel van dialektiese simbole oor God, protosemiotiek, analogiese deelname van die subjek, hiërargie, die terugvloei van alle dinge na God, unifikasie, en boosheid as ontdaande goedheid. Die vroeë skolastiek van die 11e en 12e eeue en die hoog-skolastiek van die 13e eeu sou sommige van hierdie temas direk oorneem, of met wysiging en kommentaar heraanbied, of krities transformeer. Met die Latynse vertaling van Dionisius se werke in die negende eeu is daardie proses van kritiese adopsie ook van impetus voorsien.

Dit bly daarom vreemd dat 'n figuur soos Dionisius in by verre die meeste oorsigwerke in Middeleeuse filosofie verbygegaan word, of slegs by implikasie teregkom, of as 'n betreklik ongenuanseerde voetbrug tussen Boethius en Skotus Eriugena aangebied word; as sodanig buite die spesialisnavorsing een van die baie 'onderwaardeerde' en 'ondergepubliseerde' 'eenkantfigure' in die Middeleeuse filosofie is (Beukes 2011:1). Diekritiese kwaliteit, Neoplatoniese oorspronklikheid en filosofiese erudisie laat blyke daarvan dat hierdie stil, ontwykende monnik meer en beter verdien.

Maar daarby: buiten sy nawerking in die latere Middeleeuse filosofie, staan die intrinsieke filosofiese waarde van sy Neoplatoniese refleksie vas. Dionisius was verbete ontologies in sy benadering tot elke tema waartoe die destydse rubriek van die filosofie hom toegelaat het, en is steeds hoogs leesbaar en herwaardeerbaar teen die agtergrond van die hoogbloei van subjektiewe, epistemologiese, morele en psigologiese benaderinge wanneer oor simboliek in die teologie en filosofie gepraat word in die (laat-)moderne era. Maar dit is veral die feit dat Dionisius Goddelike transendensie op só 'n radikale wyse interpreteer, dat dit enige onto-teologie verbygaan, dat transendensie nie van onder of van bo nie, maar juis van langs die immanente gejukstaponeer moet word. Daardie jukstaposisie stel ons in staat om sowel die monisme wat God skerp met die wêreld identifiseer, as die dualisme wat God teenoor die wêreld plaas, verby te gaan.

Dionisius stel ons in staat om God se transendensie te affirmeer sonder om God van die wêreld af te sny, om daarmee iets van die klassieke perspektief op die heilige, simboliese kosmos, gevul met en manifesterend van 'n transendente Goddelikheid, te herwin. Só 'n metafisika van die skepping as 'teofanie' (Perl 2007:1-16; 111-114; SheldonWilliams 1967:457-472) stel ons in staat om, vanuit die wetenskaplik-tegnologiese en beeldgemedieerde laatmoderniteit, terug te keer na 'n kontemplatiewe-liturgiese blik op die werklikheid.

Daardie skugter terugblik is Dionisius se bydrae tot 'n versoberende sensus communis (Beukes 2005:1125). Wat dit kan beteken, word in 'n opvolgartikel in terme van Dionisiese spore in Kusa se metafisika uitgewys (Beukes 2018). 


\section{Erkenning \\ Mededingende belange}

Die outeur verklaar dat hy geen finansiële of persoonlike verbintenis het met enige party wat hom nadelig kon beïnloed het in die skryf van hierdie artikel nie.

\section{Literatuurverwysings}

Anoniem, 1505-1510, De heilige Dionysius de Areopagiet in gebed, Rijksmuseum Amsterdam, viewed n.d, from https://nl.wikipedia.org/wiki/Bestand:De_heilige Dionysius_de_Areopagiet_in_gebed_Rijksmuseum_SK-A-3116.jpeg

Armstrong, A.H., 1937, 'Emanation in Plotinus', Mind 46/181, 61-66.

Armstrong, A.H., 1962, Plotinus, Collier Books, New York.

Aristoteles, 1995, 'Categoriae', in J. Barnes (red.), The complete works of Aristotle, pp. 3-25, J.L. Ackrill (vert.), Princeton University Press, Princeton, NJ.

Beierwaltes, W., 1977, Identität und Differenz: Zum Prinzip cusanischen Denkens, Rheinisch-Westfälische Akademie der Wissenschaften, Westdeutscher, Opladen.

Beierwaltes, W., 1997, Der verborgene Gott: Cusanus und Dionysius, Paulinus, Trier.

Beukes, J., 2005, 'Terreur, roes en ordes: Die monnik as blywende simbool van erns in die filosofie', HTS Teologiese Studies/Theological Studies 61, 1101-1129. https:// doi.org/10.4102/hts.v61i4.474

Beukes, J., 2011, 'God kan net doen wat God wel doen: Petrus Abelardus se Megariaanse argument in Theologia Scholarium, Opera Theologia III', HTS Teologiese Studies/Theological Studies 67(1), Art. \#124. https://doi.org/10.4102/ hts.v67i1.124. (18 Mei 2018 geraadpleeg)

Beukes, J., 2012, 'Vanaf Ockham na Kusa: Die ensiklopediese aanspraak van 'n postskolastiek in die Middeleeuse filosofie', HTS Teologiese Studies/Theological Studies
$68(1)$, Art. \#2381. https://doi.org/10.4102/hts.v68i1.1134 (14 Mei 2018 geraadpleeg).

Beukes, J., 2018, 'Dionisiese spore in Kusa se metafisika', HTS Teologiese Studies/ Theological Studies 74(4), Art. \#5112.

Billion, P. (red.), 2008, Weltbilder im Mittelalter: Perceptions of the world in the middle ages, Bernstein, Bonn.

Bosley, R.N. \& Tweedale, M., (reds.), 2004, Basic issues in medieval philosophy. Selected readings presenting the interactive discourses among the major figures, Broadview Press, Ontario.

Casarella, P.J., 2008, 'Cusanus on Dionysius: the turn to speculative theology', Modern Theology 24, 667-678.

Copleston, F.C., 1993, A history of philosophy Volume II, Medieval philosophy, Doubleday, New York.
Dillon, J., 1996, The middle Platonists: 80 B.C. - A.D.20, Cornell University Press, New York.

Duclow, D.F., 2002, 'Nicholas of Cusa's conjectural Neoplatonism', in I. Bocken (red.) On cultural ontology: Religion, philosophy and culture, pp. 71-87, Uitgeverij Shaker, Maastricht.

Gersh, S., 1986, Middle Platonism and Neoplatonism: The Latin tradition, University of Notre Dame Press, Notre Dame.

Gerson, L.P., 1994, Plotinus, Routledge, Londen.

Goosen, D., 2017, 'Die metafisiese tradisie vandag. ' $n$ Interpretasie van Eric D. Perl', Litnet Akademies 14(3), 557-591.

Haren, M., 1985, Medieval thought. The Western intellectual tradition from antiquity to the thirteenth century, Macmillan, Londen.

Hathaway, R.F., 1969, Hierarchy and the definition of order in the letters of PseudoDionysius, Nijhoff, Den Haag.

Hyman, A., Walsh, J.J. \& Williams, T., (reds.), 2010, Philosophy in the middle ages: The Christian, Islamic and Jewish traditions, Hackett, Indianapolis, IN.

Luscombe, D.E., 1997, Medieval thought, Oxford University Press, Oxford.

Marenbon, J., 1988, Early Medieval philosophy (488-1150). An introduction, Routledge, New York.

Martin, C.J.F., 1996, An introduction to Medieval philosophy, Edinburgh University Press, Edinburgh.

Merlan, P., 1967, 'Greek philosophy from Plato to Plotinus', in A.H. Armstrong (red.), The Cambridge history of later Greek and early Medieval philosophy, pp. 14-83, Cambridge University Press, Cambridge.

O'Meara, D.J., 1995, Plotinus: An introduction to the Enneads, Clarendon Press, Oxford.

O'Rourke, F., 1992, Pseudo-Dionysius and the metaphysics of Aquinas, Brill, Leiden.

Perl, E.D., 2006, 'Pseudo-Dionysius', in J.J.E. Gracia \& T.B. Noone (reds.), A companion to philosophy in the Middle Ages, pp. 540-549, Blackwell, Oxford.

Perl, E.D., 2007, Theophany: The Neoplatonic philosophy of Dionysius the Areopagite, State University of New York Press, Albany, NY.

Pseudo-Dionisius, 1988, Pseudo-Dionysius: The complete works, Luibheid, C. (vert.), Rorem, M. (vert.), Froehlich, K. (inl.), Paulist Press, New York.

Pseudo-Dionisius. 1990, Corpus Dionysiacum, B.R. Suchla, G. Heil \& A.M. Ritter (reds.), De Gruyter, Berlyn.

Rorem, P., 1993, Pseudo-Dionysius: A commentary on the texts and their influence, Oxford University Press, Oxford.

Sheldon-Williams, I.P., 1967, 'The Pseudo-Dionysius', in A.H. Armstrong (red.), The Cambridge history of later Greek and early Medieval philosophy, pp. 457-472, Cambridge University Press, Cambridge.

Tarrant, H., 2011, From the old academy to later Neoplatonism, Variorum, Ashgate.

Wagner, M.F., 2008, The enigmatic reality of time. Aristotle, Plotinus, and today, Brill, Leiden. 